\title{
New records of sea anemones (Cnidaria: Anthozoa) from Costa Rica
}

\author{
Nuevos registros de anémonas de mar (Cnidaria: Anthozoa) de Costa Rica
}

\author{
Fabián H. Acuña ${ }^{1,2}$, Agustín Garese ${ }^{1,2}$, Adriana C. Excoffon ${ }^{1,3}$ and Jorge Cortés ${ }^{4,5}$

\begin{abstract}
${ }^{1}$ Instituto de Investigaciones Marinas y Costeras (IIMyC), CONICET, Facultad de Ciencias Exactas y Naturales, Universidad Nacional de Mar del Plata, Funes 3250, 7600 Mar del Plata, Argentina. facuna@mdp.edu.ar

${ }^{2}$ Consejo Nacional de Investigaciones Científicas y Técnicas (CONICET)

${ }^{3}$ Deceased on 22-IV-2010

${ }^{4}$ Centro de Investigación en Ciencias del Mar y Limnología (CIMAR), Ciudad de la Investigación, Universidad de Costa Rica, San Pedro, 11501-2060 San José, Costa Rica

${ }^{5}$ Escuela de Biología, Universidad de Costa Rica, San Pedro, 11501-2060 San José, Costa Rica
\end{abstract}

\begin{abstract}
Resumen.- A pesar de ser componentes importantes en los sistemas marino-costeros, las anémonas de mar han sido poco estudiadas en las costas de Costa Rica. En el presente trabajo se dan a conocer registros nuevos de anémonas de mar para las costas del Caribe y Pacífico de Costa Rica, incluyendo el Parque Nacional Isla del Coco. Se han confirmado también la presencia de otras especies que habían sido registradas para Costa Rica, pero sólo en base a observaciones visuales o fotografías. Se actualiza el inventario de este grupo de cnidarios que, junto a los corallimorpharios, está constituido por 16 especies (10 en el Caribe y 6 en el Pacífico e Isla del Coco). Asimismo, se realiza una comparación entre las faunas de anémonas de mar de Costa Rica y Panamá.
\end{abstract}

Palabras clave: Actiniaria, costa del Caribe, costa del Pacífico, Isla del Coco, América Central

\begin{abstract}
Despite being important components in coastal marine systems, sea anemones have been poorly studied on both coasts of Costa Rica. In this paper new records of sea anemones are mentioned for the Caribbean and Pacific coasts of Costa Rica and the Isla del Coco National Park. Additionally, the presence of other species previously recorded in Costa Rica based on single observations or photos, is reconfirmed. An updated inventory of these cnidarians is provided, and with the corallimorpharians, comprises of 16 species (10 in the Caribbean and 6 in the Pacific and Coco Island). A comparison with the sea anemone fauna of Panama is added.
\end{abstract}

Key words: Actiniaria, Caribbean coast, Pacific coast, Cocos Island, Central America

\section{INTRODUCTION}

The study of marine biodiversity of Costa Rica has increased in recent years. However, few groups of cnidarians are relatively well studied, such as the scleractinians and octocorals of both the Pacific and Caribbean coasts (Breedy 2009, Cortés 2009a). Other groups, like the sea anemones, are poorly known and only 7 actiniarians (sea anemones sensu stricto) were mentioned by Cortés $(1997,2009 b)$ for both coasts. Subsequently, Excoffon et al. (2009) recorded and redescribed the sea anemone Nemanthus californicus Carlgren, 1940, from Archipiélago Islas Murciélago (north Pacific coast of Costa Rica). The identifications of most species mentioned by Cortés (1997) are based in single observations or photographic records and more studies are necessary to confirm these identifications. This author also mentioned the presence of the corallimorpharians Ricordea florida (Duchassaing \& Michelotti, 1860) and
Rhodactis osculifera (Le Sueur, 1817) (cited as Discosoma sanctithomae) from Cahuita National Park (Caribbean coast), these species like all corallimorpharians are considered sea anemones sensu lato. A recent paper by Acuña et al. (2012a) mentioned the occurrence of Telmatactis panamensis (Verrill, 1869) in Isla del Coco National Park, meanwhile Bradley \& Ireland (1993) mentioned the presence of $T$. cricoides (Duchassaing, 1850) (cited as T. americana) on this island, but this record is doubtful since is based on a photography and specimens were not analyzed; also Acuña et al. (2012b) recorded the sea anemone Anthopleura nigrescens (Verrill, 1928) from Mata Limón on the Pacific coast of Costa Rica.

After many field trips to both coasts of Costa Rica and the expedition UCR-UNA-COCO-I to Isla del Coco, we 
identified more species of sea anemones that constitute new records for Costa Rica and these are reported in this paper. We also provide a complete and updated inventory of sea anemones from Costa Rica and compare it with the sea anemone fauna from Panama, as studied by Garese et al. (2009).

\section{MATERIALS AND METHODS}

\section{SAMPLING SITES AND DATES}

Caribbean coast: Cahuita National Park (944'10"N; 82 $\left.48^{\prime} 37 " W\right)$ (intertidal and internal lagoon, May 2007); Puerto Viejo (9³9’32"N; 8245’09"W) (intertidal and subtidal, May 2008 and May 2010); Manzanillo (9³8'15"N; 82 $\left.{ }^{\circ} 39^{\prime} 06^{\prime \prime} \mathrm{W}\right)$ (intertidal and subtidal, May 2010). Pacific coast: Puntarenas (9॰58’35"N; 8451’03"W) (intertidal, May 2008); Caldera (955’26"N; 84² $42^{\circ} 53^{\prime \prime} \mathrm{W}$ ) (intertidal, May 2008); Malpaís (9³6’37"N; 8508’44"W) (intertidal, May 2010); Bahía Salinas [intertidal $\left(11^{\circ} 02^{\prime} 05^{\prime \prime N}\right.$; 85⒋ $\left.41^{\prime} 56^{\prime \prime} \mathrm{W}\right)$, subtidal $\left(11^{\circ} 01^{\prime} 40^{\prime \prime} \mathrm{N}\right.$; $\left.85^{\circ} 46^{\prime} 25^{\prime \prime W}\right)$, May 2010]. Isla del Coco (Expedition UCRUNA-COCO-I; April 2010): Bahía Chatham (5³2’56"N; $\left.87^{\circ} 02^{\prime} 38^{\prime \prime} \mathrm{W}\right)$ (intertidal), Punta Ulloa (5³2’59"N; $87^{\circ} 02^{\prime} 00^{\prime \prime} \mathrm{W}$ ) (subtidal).

\section{COLLECTION OF SPECIMENS OF SEA ANEMONES}

The individuals of different species were collected by hand from the intertidal zones, by snorkelling in subtidal zones, or with SCUBA at greater depths. Individuals were anesthetized by the addition of crystals of magnesium chloride, and preserved in 5\% formalin and later in $70 \%$ ethanol.

\section{TAXONOMICAL IDENTIFICATION}

The external characters of specimens were observed in the field and also in the laboratory. The internal anatomy was studied by dissections under a stereoscopic microscope. Since all specimens belonged to known species histological sections were not necessary. The cnidae was analyzed using a Zeiss ${ }^{\circledR}$ Axiolab Microscope with micrometric eyepiece at a magnification of 1000X (oil immersion). The used terminology was based on England (1991). The morphology of each species was compared and checked with previous papers (original descriptions, re-descriptions, etc.) in order to identify them. The current classification of sea anemones and the taxonomic status of some species were cross-checked with the electronic database 'Hexacorallians of the World' (Fautin 2013). Material examined is deposited at Museo de Zoología,
Universidad de Costa Rica (MZUCR), indicating for each species the catalogue number in brackets.

\section{Results}

\section{Caribbean Coast}

\section{Family ActiniIdae}

Bunodosoma granuliferum (Le Sueur, 1817)

Seven specimens of this species were collected from the intertidal zone of Puerto Viejo, inhabiting holes and cracks of dead coral. (MZUCR 2288).

Distribution other than Costa Rica: Panama and Buenaventura, Colombia (McCommas 1991); Caribbean Sea: Martinique (Le Sueur 1817); Antilles (Duchassaing 1850); Netherlands Antilles; Grand Cayman (McCommas 1991); Jamaica (Duerden 1898); Puerto Rico: Cabo Rojo (McCommas \& Lester 1980), San Juan Harbor, Hucares, Cabo Rojo and Aguadilla (Duerden 1902). India: Maharshtra, Bombay, Cuffe Parade and Breach Candy (Parulekar 1968).

Phialoba steinbecki Carlgren, 1949

Two specimens, one from the lagoon of Cahuita Reef (MZUCR 2289) and one from the intertidal zone of Puerto Viejo (MZUCR 2290) in a hole of dead coral.

Distribution other than Costa Rica: Islas Coronados and Puerto Escondido, Gulf of California, Baja California del Norte, Mexico (Carlgren, 1951), Bahía Asunción, Playa La Gaviota and Armenta, Baja California Sur, Mexico (Acuña et al. 1997).

\section{Family Phymanthidae}

Phymanthus crucifer (Le Sueur, 1817)

Eight individuals sampled from holes and cracks of dead coral in the intertidal zone of Puerto Viejo (MZUCR 2291). Also observed in Manzanillo.

Distribution other than Costa Rica: Bocas del Toro, Panama (Guzmán \& Guevara, 1998a, 1998b, 1999, 2001); Caribbean Sea: Jamaica (Duerden 1898, 1900); Bermuda (Verrill 1898, 1900, 1905); New Providence, Bahamas (McMurrich 1889); Playa Jamainitas, Cuba (Herrera Moreno 1981); Puerto Rico (Duerden 1902); Conset Bay, Barbados (Le Sueur 1817, Lewis 1960); West Indies (Verrill 1905). Crawl Key, south of Miami, Florida, USA (Carlgren 1952). 


\section{Family Aiptasitidae}

Aiptasia sp.

Six individuals collected from the intertidal zone of Puerto Viejo holes and cracks of dead coral. Since we were not able to identify these specimens to specific level they are not included in our analyses or tables. (MZUCR 2292).

\section{Pacific Coast}

\section{Family ActiniIDae}

Anthopleura elegantissima (Brandt, 1835)

Many individuals grouped in a single clone from the intertidal zone of Puntarenas under a big rock. (MZUCR 2293).

Distribution other than Costa Rica: Pacific coast of North America (Carlgren 1952).

\section{Bunodosoma grande (Verrill, 1869)}

Many specimens of the 3 colour morphotypes of this species were collected from the intertidal zone, subtidal zone and depths to $9 \mathrm{~m}$ in Bahía Salinas. (MZUCR 2296).

Distribution other than Costa Rica: Pearl Islands, Bay of Panama, Panama (Verrill 1869); Galápagos Islands, Ecuador (Fautin et al. 2007); Zorritos and Paita Perú: (Verrill 1869); Corinto and Río Brito, Nicaragua (Verrill 1869, 1870). Gulf of California, Baja California Sur, Mexico (Verrill 1870).

\section{FAMILY HoRMathiIDAE}

Calliactis polypus (Forsskål, 1775)

Several individuals were found on 2 gastropods shells inhabited by hermit crabs, collected in Bahía Salinas at 21 m depth (MZUCR 1920).

Distribution other than Costa Rica: Bahía de Achotines, Panama (Garese et al. 2009); Galápagos Islands, Ecuador (Fautin et al. 2007); Tuamotu Archipelago (Dana 1846, 1859); Cape Verde Island (Hertwig 1882); Red Sea (Klunzinger 1877); Tanzania (Carlgren 1900); Hawaii (Verrill 1928); South Africa (Carlgren 1938); Australia (Carlgren 1950a, 1950b); Aden (England 1971); Christmas Island, Kenya, Maldive Islands and Malay Straits (England 1987); Marshall Islands (Cutress \& Arneson 1987).

\section{FAMILY ISOPHELLIIDAE}

Telmatactis panamensis (Verrill, 1869)

Individual on a rock collected in Bahía Salinas at $9 \mathrm{~m}$. (MZUCR 2295). Several specimens were collected from the intertidal zone of Malpaís (MZUCR 2294).

Distribution other than Costa Rica: Panama (Verrill 1869); Easter Island, Chile (Carlgren 1922); Baja California, Mexico (Carlgren 1951); Galápagos Islands, Ecuador (Fautin et al. 2007).

\section{Isla del Coco National Park}

\section{Family ActiniIDae}

Anthopleura nigrescens (Verrill, 1928)

Five specimens under a flat stone collected from the intertidal zone of Bahía Chatham (MZUCR 1905).

Distribution other than Costa Rica: Hong Kong (England 1987, 1992). India: Bombay (Parulekar 1968), Cochin (England 1987), Mahim (Parulekar 1968). Japan: Hokkaido (Uchida 1938), Mutsu Bay (Uchida 1938). Geojedo Island, Korea (Song \& Lee 1998); Enewetok Atoll, Marshall Islands (Cutress \& Arneson 1987); Hawaii, USA (Verrill 1928, Dunn 1974, Cutress 1977, England 1987); Galápagos Islands, Ecuador (Fautin et al. 2007).

\section{FAMILY BoLOCEROIDIDAE}

Boloceroides sp.

Four individuals from Bahía Chatham buried in sediments. Since we were not able to identify them to specific level they are not included in our analyses here. These specimens have not a catalogue number yet since they are under study at IIMyC (Mar del Plata, Argentina).

\section{Discussion}

In this paper it was reported 8 new records of sea anemones for Costa Rica (Table 1) and also the presence of individuals belonging to genus Aiptasia collected from the intertidal zone of Cahuita National Park (Caribbean) that we were not able to identify at species level; we also report some individuals of genus Boloceroides from Bahía Chatham, Isla del Coco National Park). In the Caribbean of Costa Rica we found 3 new records of actiniarians: $B$. granuliferum and $P$. crucifer are common sea anemones, but the species $P$. steinbecki is a rare record since it was described from the Gulf of California and it is difficult to 
Table 1. Inventory of sea anemones from Costa Rica / Inventario de las anémonas de mar de Costa Rica

\begin{tabular}{|c|c|c|c|}
\hline Classification & $\begin{array}{c}\text { Caribbean } \\
\text { Coast }\end{array}$ & $\begin{array}{c}\text { Pacific } \\
\text { Coast }\end{array}$ & $\begin{array}{c}\text { Isla del } \\
\text { Coco }\end{array}$ \\
\hline \multicolumn{4}{|l|}{ Class Anthozoa } \\
\hline \multicolumn{4}{|l|}{ Subclass Hexacorallia } \\
\hline \multicolumn{4}{|l|}{ Order Actiniaria } \\
\hline \multicolumn{4}{|l|}{ Suborder Nyantheae } \\
\hline \multicolumn{4}{|l|}{ Infraorder Thenaria } \\
\hline \multicolumn{4}{|l|}{ Superfamily Metridioidea } \\
\hline \multicolumn{4}{|l|}{ Family Aiptasiidae } \\
\hline Bartholomea anmulata (Le Sueur, 1817) & + & & \\
\hline \multicolumn{4}{|l|}{ Family Hormathiidae } \\
\hline Calliactis polypus (Forsskål, 1775) & & + & \\
\hline \multicolumn{4}{|l|}{ Family Isophelliidae } \\
\hline Telmatactis panamensis (Verrill, 1869) & & + & + \\
\hline \multicolumn{4}{|l|}{ Family Nemanthidae } \\
\hline Nemanthus californicus Carlgren, 1940 & & + & \\
\hline \multicolumn{4}{|l|}{ Superfamily Actiniodea } \\
\hline \multicolumn{4}{|l|}{ Family Actiniidae } \\
\hline Anthopleura elegantissima (Brandt, 1835) & & + & \\
\hline Anthopleura nigrescens (Verrill, 1928) & & + & + \\
\hline Bunodosoma grande (Verrill, 1869) & & + & \\
\hline Bunodosoma granuliferum (Le Sueur, 1817) & + & & \\
\hline Condylactis gigantea (Weinland, 1860) & + & & \\
\hline Phialoba steinbecki Carlgren, 1949 & + & & \\
\hline \multicolumn{4}{|l|}{ Family Aliciidae } \\
\hline Alicia mirabilis Johnson, 1861 & + & & \\
\hline Lebrunia coralligens (Duchassaing \& Michelotti, 1860) & + & & \\
\hline \multicolumn{4}{|l|}{ Family Phymanthidae } \\
\hline Phymanthus crucifer (Le Sueur, 1817) & + & & \\
\hline \multicolumn{4}{|l|}{ Family Stichodactylidae } \\
\hline Stichodactyla helianthus (Ellis, 1768) & + & & \\
\hline \multicolumn{4}{|l|}{ Order Corallimorpharia } \\
\hline \multicolumn{4}{|l|}{ Family Discosomatidae } \\
\hline Rhodactis osculifera (Le Sueur, 1817) & + & & \\
\hline \multicolumn{4}{|l|}{ Family Ricordeidae } \\
\hline Ricordea florida Duchassaing \& Michelotti, 1860 & + & & \\
\hline
\end{tabular}

know how it could have colonized the Caribbean area, assuming its origin in the Pacific coast of North America. Therefore, the possibility of sibling species could be considered, but more specimens and DNA analysis must be performed.

Four sea anemones species are mentioned for the first time from the Pacific coast of Costa Rica. The first is A. elegantissima which was found under a big rock from the intertidal zone of Puntarenas. This species was described and recorded along the Pacific coast of North America and perhaps was introduced in Puntarenas settled on ship hulls, or by mean the ballast water. Another species is Bunodosoma grande from the intertidal and subtidal zones of Bahía Salinas, this sea anemone has at least 3 colour morphotypes and is quite abundant. Individuals of Calliactis polypus were collected at $21 \mathrm{~m}$ on hermit crabs; this is a common sea anemone in the Pacific, but had not been recorded for Costa Rica. Although the acontiarian anemone Telmatactis panamensis was recorded for Isla del Coco (Acuña et al. 2012a), in this work we found this species for the first time on the Pacific coast (Bahía Salinas) of Costa Rica. We recorded the sea anemone Anthopleura nigrescens, a common actiniarian in other Pacific islands like Galápagos and Hawaii, for the first time from Isla del Coco; it was recently reported by the Pacific coast of Costa Rica (Acuña et al. 2012b). Clearly Isla del Coco National Park needs more research effort in order to have more extensive sampling, and probably more records and perhaps new species for science will be found.

Furthermore, of the new records for Costa Rica we observed and collected specimens of species previously 
mentioned in other papers, but based on single observations or photographic records: Bartholomea annulata (Le Sueur, 1817), 4 specimens were collected from the intertidal zone of Puerto Viejo and one from Manzanillo, inhabiting holes and cracks in dead coral. One specimen was observed in Portete (Limón). This is a common sea anemone in other Caribbean zones [(Antilles (Pax 1924), Bahamas (Watzl 1922), Gulf of Mexico (Carlgren \& Hedgpeth 1952), Panama (Sebens 1976, Garese et al. 2009) and Cuba (Herrera-Moreno 1981)]. Also 2 corallimorpharians (sea anemones sensu lato) reported by Cortés (1997), were recorded from the subtidal of Manzanillo, while many individuals of $S$. helianthus were found in Cahuita, Puerto Viejo and Manzanillo on hard substrata (mainly corals) and also attached to the algae Sargassum. Cortés (1997) found one specimen in Limón assigned to genus Anthopleura, but we did not examine it to confirm the identification, therefore this record is not included in the tables.

Based on our study, the sea anemone fauna of Costa Rica is currently composed by 16 species (10 from the Caribbean and 6 from the Pacific including Isla del Coco). No endemic species are recorded for this country and most of species are shared with many other countries, especially Panama. In Table 2 a comparison between the

Table 2. Comparison of sea anemone fauna of Costa Rica and Panama / Comparación de la fauna de anémonas de mar de Costa Rica y Panamá

\begin{tabular}{|c|c|c|c|}
\hline Zone & Species & Costa Rica & Panama \\
\hline \multirow[t]{14}{*}{ Caribbean } & Alicia mirabilis Johnson, 1861 & + & \\
\hline & Bartholomea annulata (Le Sueur, 1817) & + & + \\
\hline & Bunodosoma granuliferum (Le Sueur, 1817) & + & + \\
\hline & Condylactis gigantea (Weinland, 1860) & + & + \\
\hline & Discosoma neglecta (Duchassaing \& Michelotti, 1860) & & + \\
\hline & Lebrunia coralligens (Duchassaing \& Michelotti, 1860) & + & \\
\hline & Lebrunia danae (Duchassaing \& Michelotti, 1860) & & + \\
\hline & Phialoba steinbecki Carlgren, 1949 & + & \\
\hline & Phymanthus crucifer (Le Sueur, 1817) & + & + \\
\hline & Ragactis lúcida (Duchassaing de Fonbressin \& Michelotti, 1860) & & + \\
\hline & Stichodactyla helianthus (Ellis, 1768) & + & + \\
\hline & Rhodactis osculifera (Le Sueur, 1817) & + & + \\
\hline & Ricordea florida Duchassaing \& Michelotti, 1860 & + & + \\
\hline & Subtotal & 10 & 11 \\
\hline \multirow[t]{20}{*}{ Pacific } & Actinostella bradleyi (Verrill, 1869) & & + \\
\hline & Actinostella ornata (Verrill, 1869) & & + \\
\hline & Actinothoe bradleyi (Verrill, 1869) & & + \\
\hline & Anthiparactis lineolata (Couthouy in Dana,1846) & & + \\
\hline & Anthopleura dowii Verrill, 1869 & & + \\
\hline & Anthopleura elegantissima (Brandt, 1835) & + & \\
\hline & Anthopleura nigrescens (Verrill, 1928) & + & \\
\hline & Anthopleura xanthogrammica (Brandt, 1835) & & + \\
\hline & Bunodosoma grande (Verrill, 1869) & + & + \\
\hline & Calliactis polypus (Forsskål, 1775) & + & + \\
\hline & Calliactis variegata Verrill, 1869 & & + \\
\hline & Nemanthus californicus Carlgren, 1940 & + & \\
\hline & Phellia inornata Verrill, 1869 & & + \\
\hline & Phymactis papillosa (Lesson,1830) & & + \\
\hline & Sagartia carcinophila Verrill, 1869 & & + \\
\hline & Sagartia crispata Verrill, 1869 & & + \\
\hline & Anthothoe panamensis Verrill, 1869 & & + \\
\hline & Telmatactis panamensis (Verrill, 1869) & + & + \\
\hline & Subtotal & 6 & 15 \\
\hline & Grand Total & 16 & 26 \\
\hline
\end{tabular}


inventory of species from both coasts of Costa Rica and Panama is presented, the number of species in Costa Rica is lower due presumably to a less research effort. With the exception of Anthopleura elegantissima, A. nigrescens, Nemanthus californicus, Alicia mirabilis, Lebrunia coralligens and Phialoba steinbecki, all the species found in Costa Rica were also recorded from Panama, this is to be expected taking in account that both countries belong to the Marine Provinces Tropical East Pacific and Tropical Northwestern Atlantic (Spalding et al. 2007). Certainly more research effort is needed, not only in Isla del Coco, as we mentioned above, but also in both coasts of Costa Rica in order to obtain a more complete and comprehensive inventory of sea anemones, essential in any marine invertebrate biodiversity study.

\section{AcKnowledgments}

This paper was supported partially by the grants PIP 0011 (CONICET) and EXA 556/12 (UNMdP) to FHA, and grants from the Vicerrectoría de Investigación and Oficina de Asuntos Internacionales (Académicos Visitantes) of the Universidad de Costa Rica and Consejo Nacional de Rectores de las Universidades Públicas de Costa Rica (CONARE) to JC. We're grateful to Jaime Nivia for providing us with the specimens of Calliactis polypus.

\section{LITERATURE CITED}

Acuña FH, AC Excoffon, GN Genzano \& CA SanchezOrtiz. 1997. Cnidarios bentónicos intermareales de la Región de La Bahía de La Paz. VII COLACMAR, Santos, Brasil. Tomo 1: 6-7. [Extended abstract]

Acuña FH, J Cortés \& A Garese. 2012a. Ocurrence of the sea anemone Telmatactis panamensis (Verrill, 1869) (Cnidaria: Anthozoa: Actiniaria) at Cocos Island National Park, Costa Rica. Revista de Biología Tropical 60 (Supl. 3): 201-205.

Acuña FH, J Alvarado, A Garese \& J Cortés. 2012b. First record of the sea anemone Anthopleura nigrescens (Cnidaria, Actiniaria, Actiniidae) on the Pacific coast of Central America. Marine Biodiversity Records 5: 1-3.

Bradley GE \& J Ireland. 1993. Such is life in Costa Rica underwater, 95 pp. Printex, San José.

Breedy O. 2009. Octocorals. In: Wehrtmann IS \& J Cortés (eds). Marine biodiversity of Costa Rica, Central America, pp. 161-167. Monographiae Biologicae, Springer, Berlin.

Carlgren O. 1900. Ostafrikanische Actinien. Gesammelt von Hern Dr. F. Stuhlmann 1888 und 1889. Mittheilungen aus dem Naturhistorinchen Museum 17: 21-144.
Carlgren O. 1922. Actiniaria und Zoantharia von Juan Fernandez und der Osterinsel. In: Skottsberg C (ed). The natural history of Juan Fernandez and Easter Island, pp. 145-160. Almquist \& Wiksells Boktryckeri, Uppsala.

Carlgren O. 1938. South African Actiniaria and Zoantharia. Kungliga Svenska Vetenskapsakademiens Handlingar 17: 1-148.

Carlgren O. 1950a. Corallimorpharia, Actiniaria and Zoantharia from New South Wales and South Queenslands. Arkiv für Zoologi 1(10): 131-146.

Carlgren O. 1950b. Actiniaria and Corallimorpharia. Scientific Reports of the Great Barrier Reef Expedition 1928-29 5: 427-457.

Carlgren O. 1951. The actinian fauna of the Gulf of California. Proceedings of the United States National Museum 101: 415-449.

Carlgren O. 1952. Actiniaria from North America. Arkiv für Zoologi 3(30): 373-390.

Carlgren O \& JW Hedgpeth. 1952. Actiniaria, Zoantharia and Ceriantharia from shallow water in the northwestern Gulf of Mexico. Publications of the Institute of Marine Science, University of Texas 2(2): 143-172.

Cortés J. 1997. Biodiversidad marina de Costa Rica: Filo Cnidaria. Revista de Biología Tropical 44(3)/45(1): 323334.

Cortés J. 2009a. Stony corals. In: Wehrtmann IS \& J Cortés (eds). Marine biodiversity of Costa Rica, Central America. Monographiae Biologicae, pp. 169-173. Springer, Berlin.

Cortés J. 2009b. Zoanthids, Sea Anemones and Corallimorpharians. In: Wehrtmann IS \& J Cortés (eds). Marine biodiversity of Costa Rica, Central America. Monographiae Biologicae, pp. 157-159. Springer, Berlin.

Cutress CE. 1977. Corallimorpharia, Actiniaria, Ceriantharia. In: Devaney DM \& LG Eldredge (eds). Reef and shore fauna of Hawaii, pp. 130-147. Bishop Museum Press, Honolulu.

Cutress CE \& CAArneson. 1987. Sea anemones of Enewetak Atoll. In: Devaney DM, ES Reese, BL Burch \& P Helfrich (eds). The natural history of Enewetak Atoll, pp. 53-62. Office of Scientific and Technical Information, U.S. Department of Energy, Washington.

Dana JD. 1846. Zoophytes. In: United States Exploring Expedition During the Years 1838, 1839, 1840, 1841, 1842 Under the Command of Charles Wilkes, U.S.N 7: 1- 740 pp. Lea and Blanchard, Philadelphia.

Dana JD. 1859. Synopsis of the report on zoophytes of the U.S. Exploring Expedition Around the World, Under C. Wilkes, U.S.N. Commander, in the Years 1838-1842, 172 pp. James D. Dana, New Haven. 
Duchassaing P. 1850. Animaux radiaires des Antilles, 112 pp. Imprimerie Royale, Turin.

Duerden JE. 1898. The Actiniaria around Jamaica. Journal of the Institute of Jamaica 2: 449-465.

Duerden JE. 1900. Jamaican Actiniaria. Part II. Stichodactylinae and Zoantheae. Scientific Transactions of the Royal Dublin Society 7: 133-208.

Duerden JE. 1902. Report on the actinians of Porto Rico. Bulletin of the United States Fish Commission 20: 321374.

Dunn DF. 1974. Redescription of Anthopleura nigrescens (Coelenterata, Actiniaria) from Hawaii. Pacific Science 28: 377-382.

England KW. 1971. Actiniaria from Mururoa Atoll Tuamotu, Polynesia (Hormathiidae; Calliactis polypus Sagartiidae: Verrillactis n. gen paguri). Cahiers du Pacific 15: 23-39.

England KW. 1987. Actiniaria from the Red Sea and Tropical Indo-Pacific. Bulletin of the British Museum, Natural History 53: 205-292.

England KW. 1991. Nematocysts of sea anemones (Actiniaria, Ceriantharia and Corallimorpharia: Cnidaria): nomenclature. In: Williams RB, PFS Cornelius, RG Hughes \& EA Robson (eds). Coelenterate biology: Recent research on Cnidaria and Ctenophora, pp. 691-697. Kluwer Academic Publishers, Belgium.

England KW. 1992. Actiniaria (Cnidaria: Anthozoa) from Hong Kong with additional data on similar species from Aden, Bahrain and Singapore. In: Morton B (ed). The marine flora and fauna of Hong Kong and Southern China III, pp. 699705. Proceedings of the $4^{\text {th }}$ International Marine Biological Workshop, Hong Kong University Press, Hong Kong.

Excoffon AC, FH Acuña \& J Cortés. 2009. The sea anemone Nemanthus californicus (Cnidaria, Actiniaria, Nemanthidae) from Costa Rica: re-description and first record outside the type locality. Marine Biodiversity Records 2: 1-5.

Fautin DG. 2013. Hexacorallians of the world. <http:// geoportal.kgs.ku.edu/ hexacoral/anemone2/index.cfm>

Fautin DG, CP Hickman Jr, M Daly \& T Molodtsova. 2007. Shallow-water sea anemones (Cnidaria: Anthozoa: Actiniaria) and tube anemones (Cnidaria: Anthozoa: Ceriantharia) of the Galápagos Islands. Pacific Science 61: 549-573.

Garese A, HM Guzmán \& FH Acuña. 2009. Sea anemones (Cnidaria, Anthozoa: Actiniaria and Corallimorpharia) from Panama. Revista de Biología Marina y Oceanografía 44: 791-802.

Guzmán HM \& CA Guevara. 1998a. Arrecifes coralinos de Bocas del Toro, Panamá: I. Distribución, estructura y estado de conservación de los arrecifes continentales de la Laguna de Chiriquí y la Bahía Almirante. Revista de Biología Tropical 46: 601-623.
Guzmán HM \& CA Guevara. 1998b. Arrecifes coralinos de Bocas del Toro, Panamá: II. Distribución, estructura y estado de conservación de los arrecifes de las Islas Bastimentos, Solarte, Carenero y Colón. Revista de Biología Tropical 46: 893-916.

Guzmán HM \& CA Guevara. 1999. Arrecifes coralinos de Bocas del Toro, Panamá: III. Distribución, estructura y estado de conservación de los arrecifes de las islas Pastores, Cristóbal, Popa y Cayo Agua. Revista de Biología Tropical 47: 659-675.

Guzmán HM \& CA Guevara. 2001. Arrecifes coralinos de Bocas del Toro, Panamá: IV. Distribución, estructura y estado de conservación de los arrecifes continentales de Península Valiente. Revista de Biología Tropical 49: 53-66.

Herrera-Moreno A. 1981. Nuevos registros de anémonas (Coelenterata: Actiniaria y Corallimorpharia) para aguas cubanas. Poeyana 214: 1-3.

Hertwig R. 1882. Die actinien der Challenger-Expedition, 120 pp. Gustav Fisher, Jena.

Klunzinger CB. 1877. Die Korallthiere des Rothen Meeres. 1: Die Alcyonarien und Malacodermen, 98 pp. Gutmann'schen Buchhandlung, Berlin.

Le Sueur CA. 1817. Observations on several species of the genus Actinia; illustrated by figures. Journal of the Academy of Sciences of Philadelphia 1: 149-154/169-189.

Lewis JB. 1960. The fauna of rocky shores of Barbados, West Indies. Canadian Journal of Zoology 38: 391-435.

McCommas SA. 1991. Relationships within the family Actiniidae (Cnidaria, Actiniaria) based on molecular characters. Hydrobiologia 216/217: 509-512.

McCommas SA \& LJ Lester. 1980. Electrophoretic evaluation of the taxonomic status of 2 species of sea-anemone. Biochemical Systematics \& Ecology 8: 289-292.

McMurrich JP. 1889. The Actiniaria of the Bahamas Islands, W. I. Journal of Morphology 3(1): 1-80.

Parulekar A. 1968. Sea anemones (Actiniaria) of Bombay. Journal of the Bombay Natural History Society 65: 138147.

Pax F. 1924. Actiniarien, Zoantharien und Ceriantharien von Curaçao. Kungliga Zoologisch Genootschap Natura Artis Magistra, Amsterdam 23: 93-122.

Sebens KP. 1976. The ecology of the Caribbean sea anemones in Panama: utilization of space on a coral reef. In: Mackie GO (ed). Coelenterate ecology and behavior, pp. 67-77. Plenum Press, New York.

Spalding MD, HE Fox, GR Allen, N Davidson, ZA Ferdaña, M Finlayson, BS Halpern, MA Jorge, AL Lombana, SA Lourie, KD Martin, E Mc Manus, J Molnar, CA Recchia \& J Robertson. 2007. Marine ecoregions of the world: A bioregionalization of coastal and shelf areas. BioScience 57: 573-583. 
Song JI \& IS Lee. 1998. Fauna of anthozoans from adjacent waters of Geojedo Island in Korea. Korean Journal of Systematic Zoology 14: 229-242.

Uchida T. 1938. Actiniaria of Mutsu Bay. Science Reports of Tohoku University. Fourth Series, Biology 13: 281-317.

Verrill AE. 1869. Review of the corals and polyps of the best coast of America. Transactions of the Connecticut Academy of Arts and Sciences 1: 374-558.

Verrill AE. 1870. On the geographical distribution of the polyps of the west coast of America. Transactions of the Connecticut Academy of Arts and Sciences 1: 558-567.

Verrill AE. 1898. Descriptions of new American actinians, with critical notes on other species, I. American Journal of Science and Arts 6: 493-498.
Verrill AE. 1900. Additions to the Anthozoa and Hydrozoa of the Bermudas. Anthozoa. Transactions of the Connecticut Academy of Arts and Sciences 10: 551-572.

Verrill AE. 1905. The Bermuda Islands. Part IV. Geology and paleontology and Part. V. An account of the coral reefs. Transactions of the Connecticut Academy of Arts and Sciences 12: 45-348.

Verrill AE. 1928. Hawaiian shallow water Anthozoa. Bernice P. Bishop Museum Bulletin 49: 3-30.

Watzl O. 1922. Die Actiniarien der Bahamainseln. Arkiv für Zoologi 14(24): 1-89.

Received 4 October 2012 and accepted 12 March 2013

Editor: Claudia Bustos 